\title{
庐山西北椛第四纪冰川作用 表皮构造的新发现
}

\author{
景才瑞刘昌茂罗志刚 朱兴贤 郭柏林 周中民
}

(华中师范学院地理系)

1978 年九、十月间,在卢山西北麓羊角岭终碛(前碛)蕉下, 新发现一处第四纪冰川作用表 皮构造。

关于庐山的第四纪冰川遇迹,过去已由我国卓越的科学家李四光教授 (1889-1971),进行 过比较详细的调查研究, 调查成果汇总于他的冰川代表著作《冰期之庐山》一书之中心.当时修

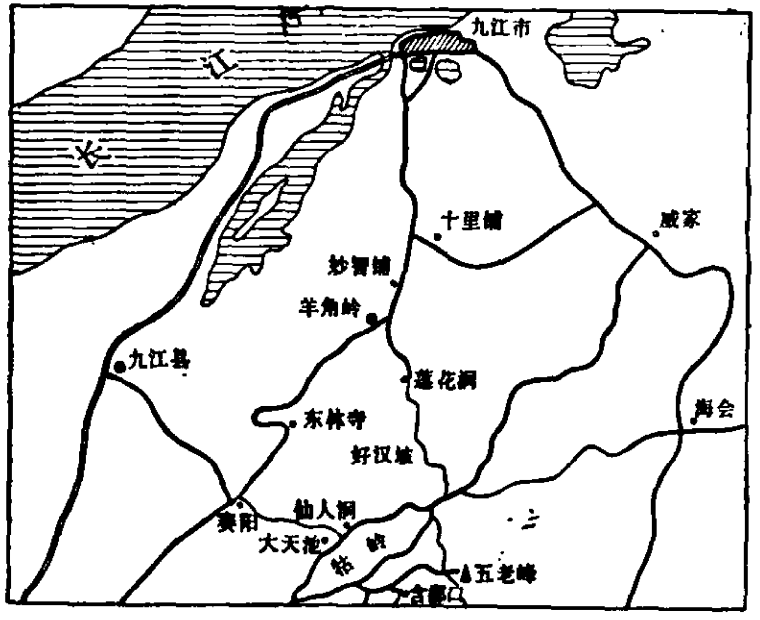

图 1 庐山西北笓羊角岭位置示意图 建山下公路,由东林寺至妙智铺这一段,适沿庐 山西北麓羊角岭终碛 (前碛) 垄后面通过 (图 1）,开挖出一段冰碛物剖面，因方向基本上与终 碛垄平行，出客的剖面上完全为第四纪冰碛物， 未见其下基岩. 近来因降坡加宽扩建公路，在 公路北侧有一与公路方向垂直的小冲沟中，簬 出一新的剖面,基本上与羊角岭终碛垄垂直，冰 碛物核心部分露出底部基岩一一寒武系薄层暗 红色页岩,由远处走近剖面观测时，恰如图 2、3 所示. 最初只望见一横切终碛䶭的剖面, 上面 掩覆的泥土很少,主要为大小混杂的冰川泥砾, 堆积在一半月形的基岩核之上 (图 2), 初视好 似有核鼓丘。但统观全局,羊角岭与莲花冰泛的冰川流动方向,并非平行,而是基本上垂直,所

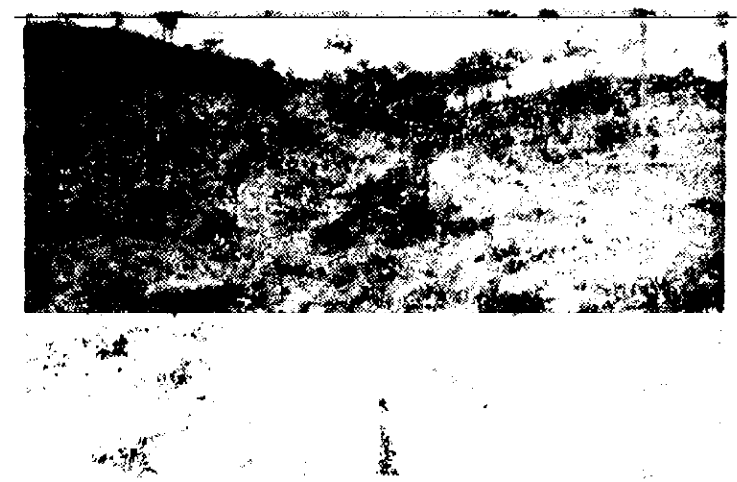

图 2 声山西北麓羊角岭终碛垄(前碛)剖面外貌 上部均为组成终碛堡的水川泥砾, 中央下部半月形处为 寨武系基岩一一薄层暗红色页岩(陈淑琴振)

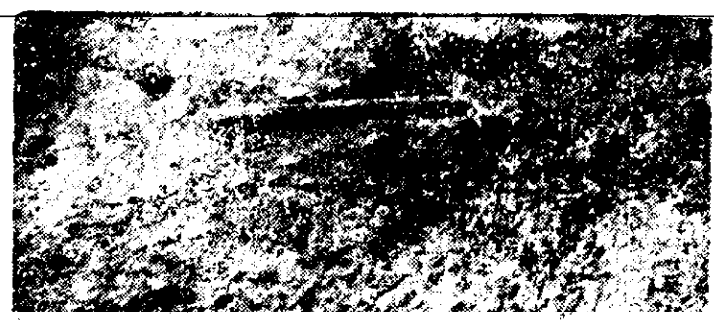

图 3 庐山西北麓羊角岭终碛垄(前碛)剖面外貌 下伏基岩表面被挤压扰动破坏, 所形成的冰川表皮构造. 地质铁锤所指方向为当时水流前进方向, 约 $\mathrm{N}^{\circ} 0^{\circ} \mathrm{W}$ （陈淑琴摄）

本文 1979 年 5 月 26 日收到. 
以它不是有核鼓丘,而应该是埋压在终碛垄下面的起伏基岩. 二者呈不整合接触,在第四纪冰 川的冰流再进之时,推动冰碛物爬越基岩小丘而过, 接触带处受到严重挤压, 下面基岩产状发 生扰乱，最上部被挤压破坏，冰碛物从南而北爬基岩埋藏坡面而上，层层迭迭,漂砾长轴排列方 向与其下基岩坡向一致,巨砾岩性为震旦系石英砂岩, 乃庐山山上震旦纪地层中之物, 非当地 寒武纪地层中所有,它们这些“外来”之物,沿基岩坡面向上爬行,若无巨大的冰川流行的搬运与 推动力是不可能形成的,越起伏基岩顶部而过后，向北顺基岩背面斜坡而下,泥砾混杂，巨砾爬 坡自然现象顿然消失,两相对比,当时第四纪冰川先携带冰碛物沿基岩斜坡向上挤压,越基岩小 丘顶部后,又顺背面斜坡下滑的形态十分清楚,真是大自然界里的一个典型的自然标本. 它不 仅是一个难得的第四纪冰川作用过的产物，而且还显示出了第四纪冰川当时流动的方向.用地 质罗盘测量下伏寒武系页岩的产状,可见基岩剖面最下部岩层比较整齐,倾向 $540^{\circ} \mathrm{E}$, 倾角很 大,有些近乎直立, 量得几处均超过 $76^{\circ}$, 整个基岩剖面长约 12 米,高约 2 米许,顶部与冰川泥 砾接触面呈弧形,整个剖面似半月形,下部未见底,往上岩层倾向变化不太大,总的方向均倾向 $\mathrm{SE}$ ，但岩层愈向上愈不整齐，最上部被扰乱破坏了，岩层倾角也愈向上俞小，呈现逐渐被当时 冰流及其所携带冰碛物压倒之势. 这绝对不可能是地质构造因素一项所能形成的. 因为在二 者接触带上,下部基岩已被挤压错动断裂, 有些当地基岩碎块被卷人上部泥砾之中，也有些上 部泥砾中从庐山顶部被冰流带下来的震旦系石英砂岩砾石,压枋入下部寒武系页岩之中,这不 仅为地质构造因素一项所不能形成,而且其他外力作用如水流、洪流、泥石流等也无法形成,因 为它们均无力将所携带的砾石压嵌人其下的基岩之中. 此处二者错综纷杂之象, 上者挤压破 坏下者,使基岩顶部发生严重扰动的原因，只能是第四纪冰川流动时的巨大挤压作用，因为基 岩以上所堆积的泥砾, 目前尚有 5 米多厚,当时冰流及其携带泥砂砾石挤压力之大是可想而知 的. 盖庐山周围的古生代地层, 均受过燕山运动的褶铍与错动, 原始地层已非平整, 此处再加 之第四纪冰川作用的巨大挤压，形成这个非常典型的第四纪冰川作用表皮构造. 过去因为它 被埋藏在冰川泥砾之下,李四光教授当时未能发现，现在由于改建扩建公路，在人工剖面上出 露地表. 基岩表层被挤压破碎情况（图 3)，十分清晰可见，铁锤所指的方向，即为当时冰流所 挤压的去向,约为 $\mathrm{N} 40^{\circ} \mathrm{W}$, 是莲花冰泛向西北方向流动时所造成的.

庐山西北簏羊角岭终碛垄下这一第四纪冰川作用表皮构造的新发现,对李四光教授的《冰 期之庐山》一书, 是一个新的补充, 它更有力地证明第四纪大冰期时, 我国东部地区的山地上, 曾有过第四纪冰川活动,不仅保存下来有明显的冰蚀地貌与冰碛地貌等遗迹,而且还在基岩表 面上保存下来这样典型的第四纪冰川作用表皮构造, 使各种古冰川遗迹, 可以成龙配套, 成为 一个整体,借以恢复第四纪时期古地理的本来面貌,有利于我们认识自然与改造利用自然.

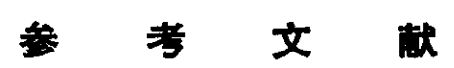

[1] 本四光, 中国第四纪冰川,科学出版社, 1975, 57-110. 